\title{
Synthesis and reactivity of ditungsten helical complex $\mathrm{W}_{2}(\mathrm{CO})_{6}(\mu-$ $\left.\mathrm{Ph}_{2} \mathrm{PC} \equiv \mathrm{CPPh}_{2}\right)_{3}$
}

\author{
Wen-Yann Yeh $^{\mathrm{a}, *}$, Shie-Ming Peng ${ }^{\mathrm{b}}$, Gene-Hsiang Lee ${ }^{\mathrm{b}}$ \\ a Department of Chemistry, National Sun Yat-Sen University, Kaohsiung 804, Taiwan \\ ${ }^{\mathrm{b}}$ Department of Chemistry, National Taiwan University, Taipei 106, Taiwan
}

Received 26 December 2002; received in revised form 14 January 2003; accepted 30 January 2003

\begin{abstract}
Reaction of $\mathrm{W}(\mathrm{CO})_{3}\left(\mathrm{Me}_{3}\right.$ tach) ( $\mathrm{Me}_{3}$ tach $=1,3,5$-trimethyl-1,3,5-triazacyclohexane) with $\mathrm{Ph}_{2} \mathrm{PC} \equiv \mathrm{CPPh}_{2}$ at room temperature affords a triply-bridged complex $\mathrm{W}_{2}(\mathrm{CO})_{6}\left(\mu-\mathrm{Ph}_{2} \mathrm{PC} \equiv \mathrm{CPPh}_{2}\right)_{3} \quad(\mathbf{1})$ and a vinylidene complex $\mathrm{W}_{2}(\mathrm{CO})_{6}\left(\mu-\mathrm{Ph}_{2} \mathrm{PC} \equiv \mathrm{CPPh}_{2}\right)[\mu-$ $\mathrm{C}_{4} \mathrm{H}\left(\mathrm{PPh}_{2}\right)_{3}$ ] (2). Compound 2 can be obtained by treating 1 with $\mathrm{Me}_{3}$ tach in dichloromethane. The crystal structures of 1 and 2 are determined by an X-ray diffraction study. The structure of $\mathbf{1}$ depicts a helical $\mathrm{M}_{2} \mathrm{~L}_{3}$ framework with an idealized $D_{3}$ symmetry. The vinylidene group of $\mathbf{2}$ is not linear, with the $\mathrm{W}=\mathrm{C}=\mathrm{C}$ bond angle of $158.6(4)^{\circ}$.
\end{abstract}

C) 2003 Elsevier Science B.V. All rights reserved.

Keywords: $\mathrm{Me}_{3}$ tach; Bis(diphenylphosphino)acetylene; 1,3,5-Trimethyl-1,3,5-triazacyclohexane

\section{Introduction}

The 'coordination clusters' assembling from monometallic complexes and multidentate bridging ligands currently attract much interest [1,2]. Frequently, the final shape of the self-assembled clusters can be predicted, which is not only defined through the metal coordination geometry but also through the orientation of the interaction sites in a given ligand [3-7]. Bis(diphenylphosphino)acetylene (dppa) is a potentially trifunctional ligand. The two phosphorus centers of dppa are normally coordinated to metals in advance of the acetylene group due to stronger net donor capability of the phosphine ligand compared with alkyne [8]. However, the rigidity of the linear $-\mathrm{C} \equiv \mathrm{C}$ - unit between two phosphorus centers forces the dppa ligand to form bonds between different metal atoms. Thus, a number of bimetallic complexes bridged by one $[9,10]$, two [11] and three [12] dppa moieties are known. In this paper, we report the synthesis of a tris( $\mu$-dppa) ditungsten helical complex and its reactivity.

* Corresponding author. Fax: +88-6-7-52539908.

E-mail address: wenyann@mail.nsysu.edu.tw (W.-Y. Yeh).

\section{Results and discussion}

The reaction of $\mathrm{W}(\mathrm{CO})_{3}\left(\mathrm{Me}_{3} \mathrm{tach}\right)$ and diphenylacetylene has been shown to give the tris(alkyne) complex $\mathrm{W}(\mathrm{CO})\left(\eta^{2}-\mathrm{PhC} \equiv \mathrm{CPh}\right)_{3} \quad$ [13]. However, treatment of $\mathrm{W}(\mathrm{CO})_{3}\left(\mathrm{Me}_{3}\right.$ tach $)$ with $\mathrm{Ph}_{2} \mathrm{PC} \equiv \mathrm{CPPh}_{2}$ in dichloromethane solvent at room temperature for 2 days produces $\mathrm{W}_{2}(\mathrm{CO})_{6}\left(\mu-\mathrm{Ph}_{2} \mathrm{PC} \equiv \mathrm{CPPh}_{2}\right)_{3}(\mathbf{1})$ in $74 \%$ yield and $\mathrm{W}_{2}(\mathrm{CO})_{6}\left(\mu-\mathrm{Ph}_{2} \mathrm{PC} \equiv \mathrm{CPPh}_{2}\right)\left[\mu-\mathrm{C}_{4} \mathrm{H}\left(\mathrm{PPh}_{2}\right)_{3}\right]$ (2) in $3 \%$ yield (Scheme 1). The reaction can be completed within $5 \mathrm{~h}$ in refluxing tetrahydrofuran (THF) but affording little $\mathbf{2}$. The triply-bridged $\mathbf{1}$ forms a paleyellow, air-stable crystalline solid which is only sparingly soluble in THF, $\mathrm{CH}_{2} \mathrm{Cl}_{2}$ and acetone. It is thermally stable in refluxing toluene $\left(110^{\circ} \mathrm{C}\right)$ and $n$ butyl ether $\left(142{ }^{\circ} \mathrm{C}\right)$ without decomposition. The IR spectrum of $\mathbf{1}$ in the carbonyl region presents two strong absorptions at 1950 and $1866 \mathrm{~cm}^{-1}$, consistent with a facial configuration for each $\mathrm{W}(\mathrm{CO})_{3}$ unit [14]. The ${ }^{1} \mathrm{H}$ NMR spectrum of 1 displays only one type of phenyl groups, and the ${ }^{31} \mathrm{P}-\mathrm{NMR}$ spectrum shows one sharp singlet at $-1.75 \mathrm{ppm}$ with appropriate ${ }^{183} \mathrm{~W}$ satellites for the equivalent phosphorus atoms. These spectral data are in agreement with a $D_{3}$ symmetry for $\mathbf{1}$ in solution. 
<smiles>CN1CN(C)[C@]2(O)CN1CN2C</smiles>

$+3$<smiles>c1ccccc1</smiles>

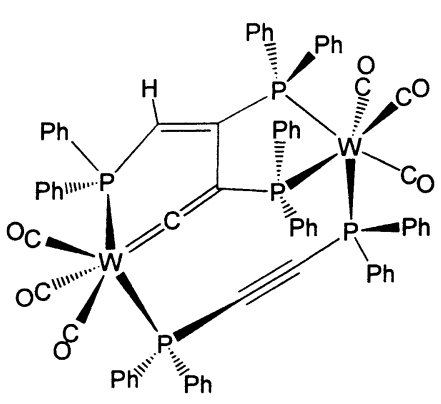
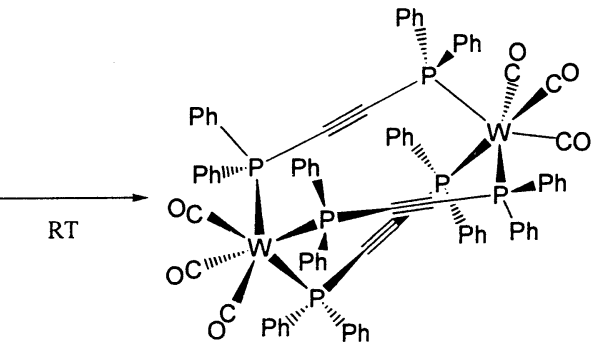

Scheme 1.

Compound 1 can be treated like three-bladed propel-

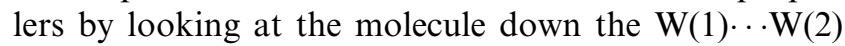
axis, where a counterclockwise $(\Lambda)$ and a clockwise $(\Delta)$ arrangement can result [15]. The crystalline material is achiral with each unit cell containing two molecules of each enantiomer. The ORTEP diagram for the $\Lambda$-enantiomer is shown in Fig. 1. The molecule consists of two facially substituted $\mathrm{W}(\mathrm{CO})_{3}$ moieties bridged by three dppa ligands. Each tungsten atom is bonded to three terminal carbonyl groups with individual $\mathrm{W}-\mathrm{C}-\mathrm{O}$ angles in the range $172(1)-177(1)^{\circ}$. The coordination about each tungsten atom is a distorted octahedral such that the $\mathrm{C}-\mathrm{W}-\mathrm{C}$ angles range from $84.3(5)^{\circ}$ to $90.0(5)^{\circ}$ and the $\mathrm{P}-\mathrm{W}-\mathrm{P}$ angles are in the range 91.2(1)$97.7(1)^{\circ}$. The $\mathrm{W}-\mathrm{P}-\mathrm{C}_{\text {(acetylene) }}$ angles show a significant deviation from the ideal tetrahedral with angles ranging from $118.2(4)^{\circ}$ to $120.6(4)^{\circ}$, consistent with steric strains arising from syn-coordination of the dppa ligands. The $\mathrm{P}-\mathrm{C} \equiv \mathrm{C}-\mathrm{P}$ backbones are slightly bowed as indicated by the $\mathrm{P}-\mathrm{C} \equiv \mathrm{C}$ angles (average $\left.177(1)^{\circ}\right)$. There is a helical

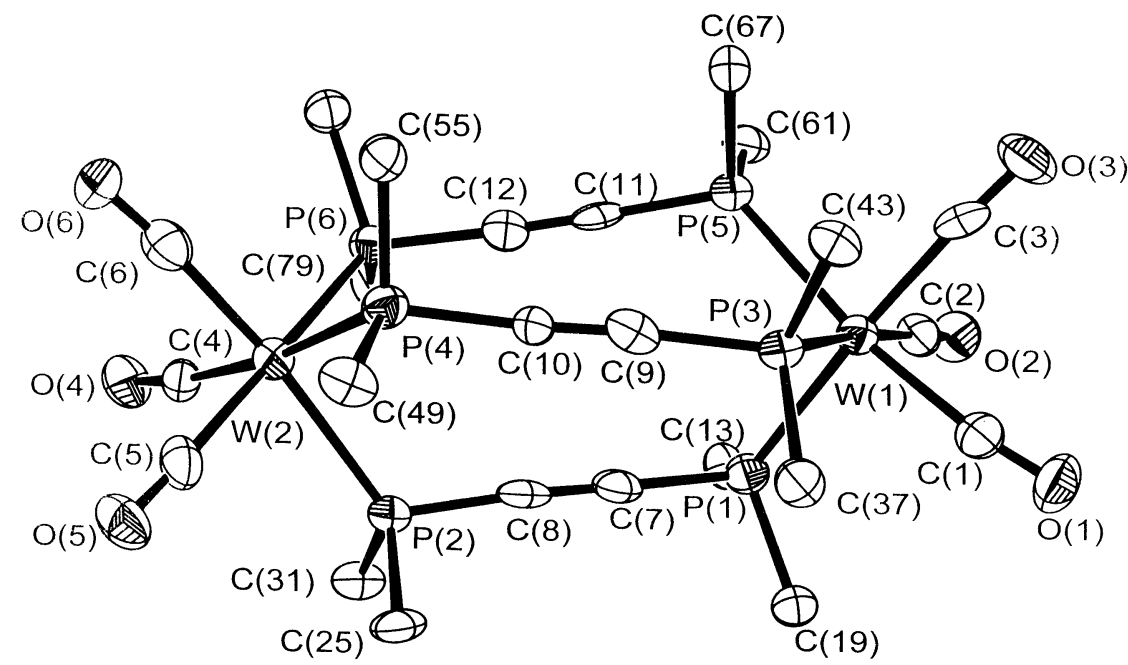

Fig. 1. Molecular structure of $\mathbf{1}$. The phenyl groups have been artificially omitted, except the ipso carbon atoms, for clarity. Selected bond distances (A): W(1)-C(1), 2.02(1); W(1)-C(2), 2.01(2); W(1)-C(3), 2.02(2); W(1)-P(1), 2.495(3); W(1)-P(3), 2.509(3); W(1)-P(5), 2.501(3); W(2)-C(4), 2.01(1); W(2)-C(5), 2.02(2); W(2)-C(6), 1.98(2); W(2)-P(2), 2.514(3); W(2)-P(4), 2.504(3); W(2)-P(6), 2.501(3); P(1)-C(7), 1.75(1); $\mathrm{P}(2)-\mathrm{C}(8)$, 1.76(1); $\mathrm{P}(3)-\mathrm{C}(9), 1.79(1) ; \mathrm{P}(4)-\mathrm{C}(10), 1.78(1) ; \mathrm{P}(5)-\mathrm{C}(11)$, 1.76(1); $\mathrm{P}(6)-\mathrm{C}(12), 1.77(1) ; \mathrm{C}(7)-\mathrm{C}(8), 1.23(2) ; \mathrm{C}(9)-\mathrm{C}(10), 1.19(2) ; \mathrm{C}(11)-\mathrm{C}(12)$, 1.21(2). Selected bond angles $\left(^{\circ}\right)$ : $\mathrm{C}(1)-\mathrm{W}(1)-\mathrm{C}(2)$, 86.6(5); $\mathrm{C}(1)-\mathrm{W}(1)-\mathrm{C}(3), 84.3(5) ; \mathrm{C}(2)-\mathrm{W}(1)-\mathrm{C}(3)$, 88.8(5); $\mathrm{P}(1)-\mathrm{W}(1)-\mathrm{P}(3)$, 93.9(1); $\mathrm{P}(1)-$ $\mathrm{W}(1)-\mathrm{P}(5), 95.7(1) ; \mathrm{P}(3)-\mathrm{W}(1)-\mathrm{P}(5), 91.2(1) ; \mathrm{C}(4)-\mathrm{W}(2)-\mathrm{C}(5), 90.0(5) ; \mathrm{C}(4)-\mathrm{W}(2)-\mathrm{C}(6), 84.6(5) ; \mathrm{C}(5)-\mathrm{W}(2)-\mathrm{C}(6), 86.0(5) ; \mathrm{P}(2)-\mathrm{W}(2)-\mathrm{P}(4)$, 93.0(1); $\mathrm{P}(2)-\mathrm{W}(2)-\mathrm{P}(6)$, 92.8(1); $\mathrm{P}(4)-\mathrm{W}(2)-\mathrm{P}(6)$, 94.3(1); W(1)-P(1)-C(7), 118.9(4); W(1)-P(3)-C(9), 118.7(4); W(1)-P(5)-C(11), 118.8(4); $\mathrm{W}(2)-\mathrm{P}(2)-\mathrm{C}(8), 118.2(4) ; \mathrm{W}(2)-\mathrm{P}(4)-\mathrm{C}(10), 120.6(4) ; \mathrm{W}(2)-\mathrm{P}(6)-\mathrm{C}(12), 118.3(4) ; \mathrm{P}(1)-\mathrm{C}(7)-\mathrm{C}(8), 178(1) ; \mathrm{P}(2)-\mathrm{C}(8)-\mathrm{C}(7), 176(1) ; \mathrm{P}(3)-\mathrm{C}(9)-$ $\mathrm{C}(10), 176(1) ; \mathrm{P}(4)-\mathrm{C}(10)-\mathrm{C}(9), 176(1) ; \mathrm{P}(5)-\mathrm{C}(11)-\mathrm{C}(12), 178(1) ; \mathrm{P}(6)-\mathrm{C}(12)-\mathrm{C}(11), 178(1)$. 
twist of ca. $21^{\circ}$ about the $\mathrm{W}(1) \cdots \mathrm{W}(2)$ axis, taking as the average of the torsion angles: $\mathrm{P}(1)-\mathrm{W}(1)-\mathrm{W}(2)-$ $\mathrm{P}(2) 19.3^{\circ}, \mathrm{P}(3)-\mathrm{W}(1)-\mathrm{W}(2)-\mathrm{P}(4) \quad 19.3^{\circ}$ and $\mathrm{P}(5)-$ $\mathrm{W}(1)-\mathrm{W}(2)-\mathrm{P}(6) 24.7^{\circ}$. The related helical tris(dppa) complexes are $\mathrm{Ni}_{2}(\mathrm{CO})_{2}(\mathrm{dppa})_{3}$ [16], $\left[\mathrm{Ag}_{2}(\mathrm{dppa})_{3}\right]^{2+}$ [17], $\mathrm{Mo}_{2}(\mathrm{CO})_{6}(\mathrm{dppa})_{3}$ [12] and $(\mathrm{BuTe})_{2} \mathrm{Cu}_{2}(\mathrm{dppa})_{3}$ [18]. There are substantially intramolecular aromatic contacts between the 12 phenyl groups, as shown in Fig. 2. In combination of these contacts should restrict free rotation of the phenyl groups to account for poor solubility of $\mathbf{1}$ in organic solvents. There is small void at the center, such that the $\mathrm{W}(1) \cdots \mathrm{W}(2)$ distance is 7.39 $\AA$ and the distances between $\mathrm{C} \equiv \mathrm{C}$ centroids are $3.54 \AA$ in average.

Compound 2 forms a purple-red, air-stable crystalline solid. It is soluble in common organic solvents. The IR spectrum in the carbonyl region displays four stretching absorptions, suggesting different environments for the two $\mathrm{W}(\mathrm{CO})_{3}$ groups. The ${ }^{1} \mathrm{H}-\mathrm{NMR}$ spectrum shows a very complex multiplet in the range $7.85-6.43 \mathrm{ppm}$ for the phenyl protons and a multiplet of ${ }^{1} \mathrm{H}$ at $5.84 \mathrm{ppm}$ for an alkene proton. The most striking feature is that the ${ }^{31} \mathrm{P}-\mathrm{NMR}$ spectrum presents five multiplets of about equal intensities at $57.8,49.4,31.8,-5.1$ and $-6.3 \mathrm{ppm}$ with each accompanied by appropriate ${ }^{183} \mathrm{~W}$ satellites. Because of the absence of diagnostic spectral features to reveal the structure of $\mathbf{2}$, a single-crystal X-ray diffraction study was performed.

The molecular structure of $\mathbf{2}$, shown in Fig. 3, consists of two $\mathrm{fac}-\mathrm{W}(\mathrm{CO})_{3}$ groups bridged by a dppa ligand and a tris(diphenylphosphino)vinylvinylidene species. The coordination about the $\mathrm{W}(2)$ atom resembles the parent compound $\mathbf{1}$, while the $\mathrm{W}(1)$ atom is connected to three terminal carbonyls, two phosphines and a vinylidene ligand. The atoms $\mathrm{C}(7), \mathrm{C}(8), \mathrm{C}(9), \mathrm{P}(2)$ and $\mathrm{P}(3)$ are

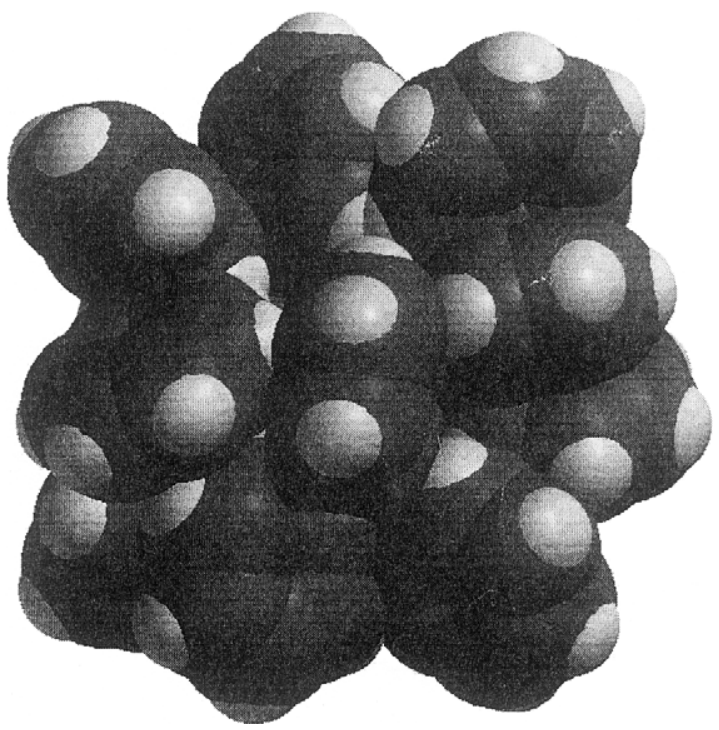

Fig. 2. Space filling representation of the phenyl groups in $\mathbf{1}$ to show the intramolecular aromatic contacts. about on the same plane, while the $\mathrm{C}(9)-\mathrm{C}(10)$ and $\mathrm{C}(7)-\mathrm{P}(1)$ vectors are bent away from this plane by ca. $10^{\circ}$. The $C(7)-C(8)$ and $C(9)-C(10)$ lengths of $1.345(6)$ and 1.329(6) $\AA$ are characteristic of a carbon-carbon double bond, which are shorter than the $\mathrm{C}(8)-\mathrm{C}(9)$ single-bond distance of 1.475(6) $\AA$ and longer than the $\mathrm{C}(11)-\mathrm{C}(12)$ triple-bond distance of 1.214(6) $\AA$. The $\mathrm{C}(10)$ atom appears to form a double-bond to the W(1) atom with the interatomic distance of 1.954(4) $\AA$, which is comparable with those measured for the tungstencarbene lengths in $\mathrm{W}\left(\mathrm{C}_{2} \mathrm{Ph}_{2}\right)\left(\mathrm{C}_{8} \mathrm{Ph}_{8}\right)(2.02 \AA)$ [19] and $\mathrm{W}(\mathrm{CO})\left(\mathrm{C}_{2} \mathrm{Ph}_{2}\right)\left(\mathrm{C}_{8} \mathrm{Ph}_{8}\right)$ (2.01 $\AA$ ) [20]. Noticeably, the vinylidene $\mathrm{W}(1)=\mathrm{C}(10)=\mathrm{C}(9)$ angle of $158.6(4)^{\circ}$ is significantly deviated from linearity by $21.4^{\circ}$, presumably due to steric strains inside the $\mathrm{WPC}_{4}$ ring.

Compound $\mathbf{1}$ is stable in dichloromethane, but it decomposes slowly when $\mathrm{Me}_{3}$ tach is added into the solution to produce $\mathbf{2}$ as one of the products. Apparently the base ' $\mathrm{Me}_{3}$ tach', either being added or released from $\mathrm{W}(\mathrm{CO})_{3}\left(\mathrm{Me}_{3} \mathrm{tach}\right)$, might induce 1 to undergo sequential transformations, including $\mathrm{C}-\mathrm{C}$ coupling, $\mathrm{PPh}_{2}$ elimination and hydrogen abstraction, to give 2, though the exact pathways are still unclear. There are three uncoordinated acetylene units in $\mathbf{1}$. However, attempts to react 1 with $\mathrm{Co}_{2}(\mathrm{CO})_{8}$ or $\mathrm{Ni}(\mathrm{COD})_{2}$ gave no reactions. Hong et al. [21] have shown that treating $\mathrm{Co}_{2}(\mathrm{CO})_{8}$ with dppa yields a tetracobalt cluster bonded to both the phosphine and the acetylene moieties. It is probably the intramolecular phenyl stacking (Fig. 2) that prevents metal atom(s) from binding the acetylene groups. We are currently investigating if a small metal cation can be trapped inside the cavity of 1 through $\pi$ interactions.

\section{Experimental}

\subsection{General methods}

All manipulations were carried out under an atmosphere of purified dinitrogen with standard Schlenk techniques. $\quad \mathrm{W}(\mathrm{CO})_{3}\left(\mathrm{Me}_{3} \mathrm{tach}\right) \quad\left(\mathrm{Me}_{3} \mathrm{tach}=1,3,5\right.$-trimethyl-1,3,5-triazacyclohexane) was prepared from $\mathrm{W}(\mathrm{CO})_{6}$ as described in the literature [13]. $\mathrm{Ph}_{2} \mathrm{PC} \equiv$ $\mathrm{CPPh}_{2}$ was purchased from Aldrich and used as received. Solvents were dried over appropriate reagents under dinitrogen and distilled immediately before use. Preparative thin-layer chromatographic (TLC) plates were prepared from silica gel (Kieselgel, $\mathrm{DGF}_{254}$ ). Infrared spectra were recorded with a $0.1 \mathrm{~mm}$ path $\mathrm{CaF}_{2}$ solution cell on a Hitachi I-2001 IR spectrometer. ${ }^{1} \mathrm{H}$ - and ${ }^{31} \mathrm{P}-\mathrm{NMR}$ spectra were obtained on a Varian VXR-300 spectrometer. Fast-atom-bombardment (FAB) mass spectra were recorded by using a VG Blotch-5022 mass spectrometer. Elemental analyses 


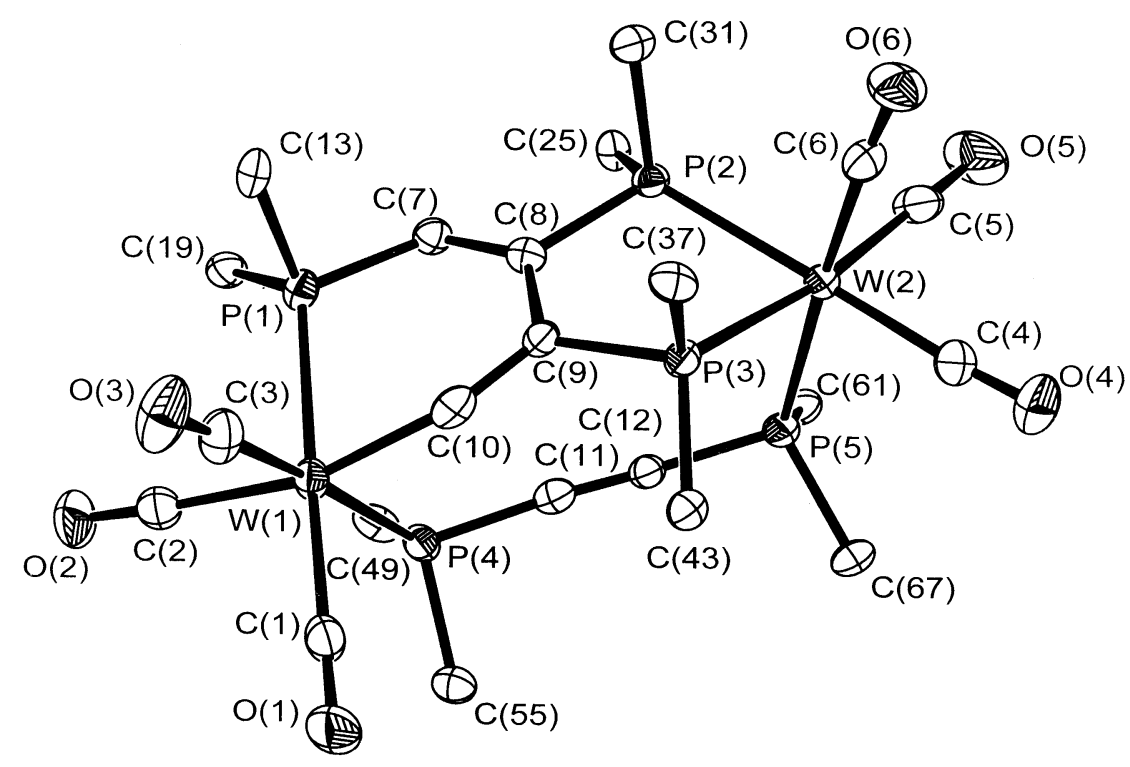

Fig. 3. Molecular structure of 2 . The phenyl groups have been artificially omitted, except the ipso carbon atoms, for clarity. Selected bond distances $(\AA)$ : W(1)-C(1), 2.040(5); W(1)-C(2), 2.088(5); W(1)-C(3), 1.990(5); W(1)-C(10), 1.954(5); W(1)-P(1), 2.495(1); W(1)-P(4), 2.535(1); W(2)-C(4), 1.985(5); W(2)-C(5), 1.983(5); W(2)-C(6), 1.982(6); W(2)-P(2), 2.509(1); W(2)-P(3), 2.500(1); W(2)-P(5), 2.525(1); P(1)-C(7), 1.809(5); $\mathrm{P}(2)-\mathrm{C}(8)$, 1.862(5); $\mathrm{C}(7)-\mathrm{C}(8), 1.345(6) ; \mathrm{P}(3)-\mathrm{C}(9), 1.826(5) ; \mathrm{C}(8)-\mathrm{C}(9), 1.475(6) ; \mathrm{C}(9)-\mathrm{C}(10), 1.329(6) ; \mathrm{P}(4)-\mathrm{C}(11), 1.778(5) ; \mathrm{P}(5)-\mathrm{C}(12), 1.770(5) ; \mathrm{C}(11)-$ $\mathrm{C}(12)$, 1.214(6). Selected bond angles $\left(^{\circ}\right)$ : $\mathrm{P}(1)-\mathrm{W}(1)-\mathrm{C}(10)$, 74.0(1); $\mathrm{W}(1)-\mathrm{C}(10)-\mathrm{C}(9), 158.6(4) ; \mathrm{C}(10)-\mathrm{C}(9)-\mathrm{C}(8), 115.3(4)$; $\mathrm{C}(10)-\mathrm{C}(9)-\mathrm{P}(3)$, 124.3(3); $\mathrm{C}(8)-\mathrm{C}(9)-\mathrm{P}(3), 119.8(3) ; \mathrm{C}(9)-\mathrm{C}(8)-\mathrm{C}(7), 124.8(4) ; \mathrm{C}(9)-\mathrm{C}(8)-\mathrm{P}(2), 115.8(3) ; \mathrm{C}(7)-\mathrm{C}(8)-\mathrm{P}(2), 119.5(3) ; \mathrm{C}(8)-\mathrm{C}(7)-\mathrm{P}(1), 123.2(4)$; $\mathrm{C}(7)-\mathrm{P}(1)-\mathrm{W}(1), 113.3(2) ; \mathrm{C}(11)-\mathrm{C}(12)-\mathrm{P}(5), 173.8(4) ; \mathrm{C}(12)-\mathrm{C}(11)-\mathrm{P}(4), 173.8(4)$.

were performed at the National Chen-Kung University, Tainan, Taiwan.

\subsection{Reaction of $\mathrm{W}(\mathrm{CO})_{3}\left(\mathrm{Me}_{3}\right.$ tach) with $\mathrm{Ph} \mathrm{h}_{2} \mathrm{PC} \equiv$ $\mathrm{CPPh}_{2}$}

$\mathrm{W}(\mathrm{CO})_{3}\left(\mathrm{Me}_{3}\right.$ tach $)(500 \mathrm{mg}, 1.26 \mathrm{mmol})$ and $\mathrm{Ph}_{2} \mathrm{PC} \equiv$ $\mathrm{CPPh}_{2}(800 \mathrm{mg}, 2.01 \mathrm{mmol})$ were placed in an ovendried $100 \mathrm{ml}$ Schlenk flask, equipped with a magnetic stir bar and a rubber serum stopper. Freshly distilled dichloromethane $(100 \mathrm{ml})$ was introduced into the flask via a syringe through the serum stopper. The mixture was stirred at room temperature for 2 days, resulting in an orange solution. The mixture was filtered into a Schlenk tube, and the filtrate was carefully layered with $n$-hexane $(100 \mathrm{ml})$ and left to settle at ambient temperature. Bright yellow crystals of $\mathrm{W}_{2}(\mathrm{CO})_{6}\left(\mu-\mathrm{Ph}_{2} \mathrm{PC} \equiv\right.$ $\left.\mathrm{CPPh}_{2}\right)_{3}(1 ; 805 \mathrm{mg}, 0.47 \mathrm{mmol}, 74 \%$ based on $\mathrm{W}$ atoms) were afforded. The mother liquid was evaporated to dryness on a rotary evaporator, and the residue was subjected to TLC with $n$-hexane/dichloromethane $\left(1: 1, \mathrm{v} \mathrm{v}^{-1}\right)$ as eluant. Crystallization of the material forming the orange band from benzene $/ n$-hexane produced purple-red, plate crystals of $\mathrm{W}_{2}(\mathrm{CO})_{6}\left(\mu-\mathrm{Ph}_{2} \mathrm{PC} \equiv\right.$ $\left.\mathrm{CPPh}_{2}\right)\left[\mu-\mathrm{C}_{4} \mathrm{H}\left(\mathrm{PPh}_{2}\right)_{3}\right](2 ; 35 \mathrm{mg}, 3.4 \%)$.

1: IR $\left(\mathrm{CH}_{2} \mathrm{Cl}_{2}, v_{\mathrm{CO}}\right): 1950 \mathrm{vs}, 1866 \mathrm{vs} \mathrm{cm}{ }^{-1} .{ }^{1} \mathrm{H}-\mathrm{NMR}$ $\left(\mathrm{CD}_{2} \mathrm{Cl}_{2}, 25^{\circ} \mathrm{C}\right): 7.40(\mathrm{t}, 12 \mathrm{H}), 7.25(\mathrm{t}, 24 \mathrm{H}), 7.04(\mathrm{t}, J=$ $8 \mathrm{~Hz}, 24 \mathrm{H})$ ppm. ${ }^{31} \mathrm{P}\left\{{ }^{1} \mathrm{H}\right\}-\mathrm{NMR}\left(\mathrm{CD}_{2} \mathrm{Cl}_{2}, 25^{\circ} \mathrm{C}\right)$ : -1.75 (s, with ${ }^{183} \mathrm{~W}$ satellites, $J_{\mathrm{W}-\mathrm{P}}=235 \mathrm{~Hz}$ ) ppm.
Anal. found: $\mathrm{C}, 58.22 ; \mathrm{H}, 3.40 . \mathrm{C}_{84} \mathrm{H}_{60} \mathrm{O}_{6} \mathrm{P}_{6} \mathrm{~W}_{2}$ Anal. Calc.: C, 58.69; $\mathrm{H}, 3.52 \%$.

2: IR $\left(\mathrm{CH}_{2} \mathrm{Cl}_{2}, v_{\mathrm{CO}}\right): 1966 \mathrm{~s}, 1944 \mathrm{vs}, 1906 \mathrm{w}, 1850 \mathrm{~m}$ $\mathrm{cm}^{-1} .{ }^{1} \mathrm{H}-\mathrm{NMR}\left(\mathrm{CD}_{2} \mathrm{Cl}_{2}, 25^{\circ} \mathrm{C}\right): 7.85-6.43(\mathrm{~m}, 50 \mathrm{H}$, $\mathrm{Ph}), 5.84(\mathrm{~m}, 1 \mathrm{H}, \mathrm{CH}=)$ ppm. ${ }^{31} \mathrm{P}\left\{{ }^{1} \mathrm{H}\right\}-\mathrm{NMR}\left(\mathrm{CD}_{2} \mathrm{Cl}_{2}\right.$, $\left.25^{\circ} \mathrm{C}\right): 57.8\left(\mathrm{~m}, 1 \mathrm{P}\right.$, with ${ }^{183} \mathrm{~W}$ satellites, $J_{\mathrm{W}-\mathrm{P}}=226 \mathrm{~Hz}$ ), $49.4\left(\mathrm{~m}, 1 \mathrm{P}\right.$, with ${ }^{183} \mathrm{~W}$ satellites, $\left.J_{\mathrm{W}-\mathrm{P}}=228 \mathrm{~Hz}\right), 31.8$ $\left(\mathrm{m}, 1 \mathrm{P}\right.$, with ${ }^{183} \mathrm{~W}$ satellites, $\left.J_{\mathrm{W}-\mathrm{P}}=204 \mathrm{~Hz}\right),-5.1(\mathrm{~m}$, $1 \mathrm{P}$, with ${ }^{183} \mathrm{~W}$ satellites, $\left.J_{\mathrm{W}-\mathrm{P}}=215 \mathrm{~Hz}\right),-6.3(\mathrm{~m}, 1 \mathrm{P}$, with ${ }^{183} \mathrm{~W}$ satellites, $\left.J_{\mathrm{W}-\mathrm{P}}=242 \mathrm{~Hz}\right) \mathrm{ppm}$. MS $(\mathrm{FAB})$ $m / z 1534\left[\mathrm{M}^{+},{ }^{184} \mathrm{~W}\right]$.

\subsection{Transformation of 1 into 2}

A solution of $1(20 \mathrm{mg})$ in dichloromethane $(20 \mathrm{ml})$ was added into a Schenk flask under dinitrogen, and the mixture was stirred at room temperature for $24 \mathrm{~h}$, showing no reactions as evidenced by IR and TLC. $\mathrm{Me}_{3}$ tach $(10 \mu \mathrm{l})$ was then introduced, and the mixture was stirred for another $24 \mathrm{~h}$, resulting an orange solution. Compound $\mathbf{2}$ was obtained after separation, accompanied with several uncharacterized products.

\subsection{Structure determination for $\mathbf{1}$ and $\mathbf{2}$}

Crystals of $\mathbf{1}$ and $\mathbf{2}$ suitable for X-ray diffraction studies were grown from dichloromethane/ $n$-hexane and benzene/ $n$-hexane at ambient temperature, respectively. They were each mounted in a thin-walled glass capillary and aligned on the Nonius Kappa CCD diffractometer 
Table 1

Crystal data and refinement details for $\mathbf{1}$ and $\mathbf{2}$

\begin{tabular}{|c|c|c|}
\hline & 1 & 2 \\
\hline $\begin{array}{l}\text { Formula } \\
T(\mathrm{~K}) \\
\text { Crystal system } \\
\text { Crystal solvent } \\
\text { Space group }\end{array}$ & $\begin{array}{l}\mathrm{C}_{84} \mathrm{H}_{60} \mathrm{O}_{6} \mathrm{P}_{6} \mathrm{~W}_{2} \\
150(1) \\
\text { triclinic } \\
P \overline{1}\end{array}$ & $\begin{array}{l}\mathrm{C}_{72} \mathrm{H}_{51} \mathrm{O}_{6} \mathrm{P}_{5} \mathrm{~W}_{2} \\
150 \\
\text { orthorhombic } \\
\mathrm{C}_{6} \mathrm{H}_{6} \\
P \text { bcn }\end{array}$ \\
\hline $\begin{array}{l}\text { Unit cell dimensi } \\
a(\AA) \\
b(\AA) \\
c(\AA) \\
\alpha\left(\left(^{\circ}\right)\right. \\
\beta\left({ }^{\circ}\right) \\
\gamma\left({ }^{\circ}\right)\end{array}$ & $\begin{array}{l}13.5488(3) \\
13.6484(3) \\
23.1937(7) \\
73.814(1) \\
88.412(1) \\
60.599(1)\end{array}$ & $\begin{array}{l}38.3452(2) \\
17.3030(1) \\
20.2987(1) \\
90 \\
90 \\
90 \\
134679(1)\end{array}$ \\
\hline $\begin{array}{l}V\left(\AA^{3}\right) \\
Z\end{array}$ & $\begin{array}{l}3557.8(2) \\
2\end{array}$ & $\begin{array}{l}13467.9(1) \\
8\end{array}$ \\
\hline $\begin{array}{l}D_{\text {calc }}\left(\mathrm{g} \mathrm{cm}^{-1}\right) \\
F\left(\begin{array}{lll}0 & 0 & 0\end{array}\right)\end{array}$ & $\begin{array}{l}1.604 \\
1700\end{array}$ & $\begin{array}{l}1.592 \\
6376\end{array}$ \\
\hline $\begin{array}{l}\text { Radiation } \lambda(\AA) \\
\mu\left(\mathrm{mm}^{-1}\right) \\
\left.\theta \text { range }{ }^{\circ}\right)\end{array}$ & $\begin{array}{l}0.71073 \\
3.421 \\
1.74-25.00\end{array}$ & $\begin{array}{l}0.71073 \\
3.586 \\
1.06-27.50\end{array}$ \\
\hline $\begin{array}{l}\theta \text { range }\left(^{\circ}\right) \\
R_{1} \\
\mathrm{w} R_{2} \\
\text { GOF on } F^{2}\end{array}$ & $\begin{array}{l}1.74-25.00 \\
0.0712 \\
0.1716 \\
1.269\end{array}$ & $\begin{array}{l}1.06-27.50 \\
0.0391 \\
0.0826 \\
1.102\end{array}$ \\
\hline
\end{tabular}

with graphite-monochromated $\mathrm{Mo}-\mathrm{K} \alpha$ radiation $(\lambda=$ $0.71073 \AA$ ). The data were collected at $150 \mathrm{~K}$. All data were corrected for the effects of absorption. The structures were solved by the direct method and refined by full-matrix least-squares on $F^{2}$. The program used was the SHELXTL package [22]. All non-hydrogen atoms were refined with anisotropic displacement parameters. Hydrogen atoms were included but not refined. A summary of relevant crystallographic data is provided in Table 1 .

\section{Supplementary material}

Crystallographic data for the structural analysis of $\mathbf{1}$ and $\mathbf{2}$ have been deposited with the Cambridge Crystallographic Data Centre, CCDC No. 199849 and 199850, respectively. Copy of this information may be obtained free of charge from: The Director, CCDC, 12 Union Road, Cambridge CB2 1EZ, UK (Fax: +44-1223-
336033 or email: deposit@ccdc.cam.ac.uk or www: http://www.ccdc.cam.ac.uk).

\section{Acknowledgements}

We are grateful to the National Science Council of Taiwan for support of this work.

\section{References}

[1] N. Takeda, K. Umemoto, K. Yamaguchi, M. Fujita, Nature 398 (1999) 794.

[2] B. Olenyuk, J.A. Whiteford, A. Fechtenkotter, P.J. Stang, Nature 398 (1999) 769.

[3] M. Fujita, Chem. Soc. Rev. (1998) 417.

[4] S. Leininger, B. Olenyuk, P.J. Stang, Chem. Rev. 100 (2000) 853.

[5] M. Fujita, K. Umemoto, M. Yoshizawa, N. Fujita, T. Kusukawa, K. Biradha, Chem. Commun. (2001) 509.

[6] B.J. Holliday, C.A. Mirkin, Angew. Chem. Int. Ed. 40 (2001) 2022.

[7] S.R. Seidei, P.J. Stang, Acc. Chem. Res. 35 (2002) 972.

[8] R.H. Crabtree, The Organometallic Chemistry of the Transition Metals, 3rd ed., Wiley, New York, 2001

[9] B.F.G. Johnson, J. Lewis, A.D. Massey, P.R. Raithby, W.T. Wong, J. Organomet. Chem. 397 (1990) C28.

[10] E. Louattani, J. Suades, J. Organomet. Chem. 604 (2000) 234.

[11] L.R. Falvello, J. Forniés, J. Gómez, E. Lalinde, A. Martín, F. Martínez, M.T. Moreno, J. Chem. Soc. Dalton Trans. (2001) 2132.

[12] G. Hogarth, T. Norman, Polyhedron 15 (1996) 2859.

[13] M.V. Baker, M.R. North, J. Organomet. Chem. 565 (1998) 225

[14] S.C.N. Hsu, W.-Y. Yeh, J. Chem. Soc. Dalton Trans. (1998) 125.

[15] G.L. Miessler, D.A. Tarr, Inorganic Chemistry, 2nd ed., PrenticeHall, Englewood Cliffs, NJ, 2000.

[16] A.J. Carty, A. Efraty, T.W. Ng, Can. J. Chem. 47 (1969) 1429.

[17] S.L. James, E. Lozano, M. Nieuwenhuyzen, Chem. Commun. (2000) 617.

[18] M. Semmelmann, D. Fenske, J.F. Corrigan, J. Chem. Soc. Dalton Trans. (1998) 2541.

[19] W.-Y. Yeh, C.-L. Ho, M.Y. Chiang, I.-T. Chen, Organometallics 16 (1997) 2698.

[20] W.-Y. Yeh, S.-M. Peng, G.-H. Lee, J. Chem. Soc. Chem. Commun. (1993) 1056

[21] F.-E. Hong, H. Chang, Y.-C. Chang, B.-T. Ko, Inorg. Chem. Commun. 4 (2001) 723.

[22] G.M. Sheldrick, SHELXTL, University of Göttingen, Germany, 1985. 